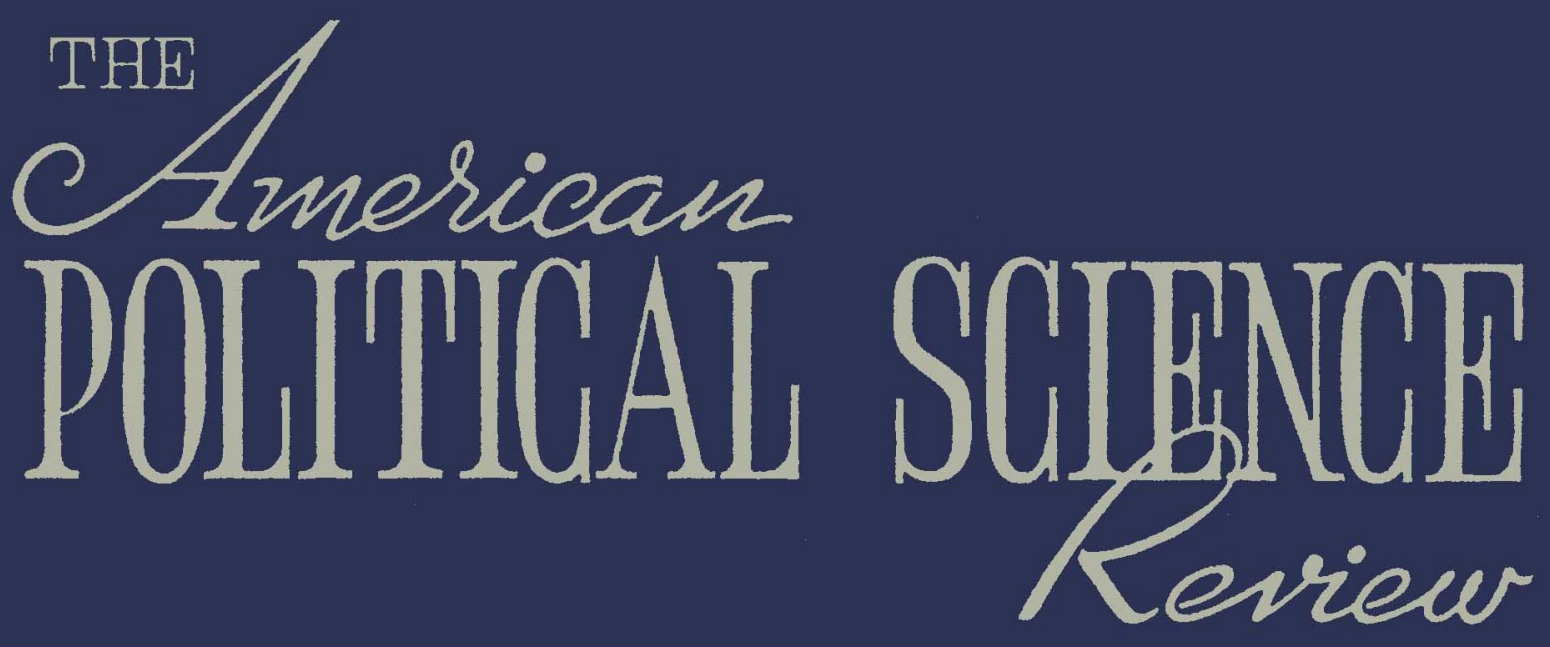

Vol. LV

Social Mobilization and Political Development ....... Karl W. Deutsch ..... 493

Measurement of Latin American Political Change ..... Russell H. Fitzgibbon and

Big Business Lobbying in Japan: The Case of Central Kenneth $F$. Johnson .. 515

Bank Reform ........................... Frank $C$. Langdon .... 527

The Elected and the Anointed $\ldots \ldots \ldots \ldots \ldots \ldots \ldots$ Andrew Hacker ...... 539

The Behavioral Sciences and the Study of Political Things:

The Case of Christian Bay's The Structure of Freedom Walter Berns ........ 550

The Necessity of Historicism .............. Glenn Tinder ....... 560

The Outsider in the Senate: An Alternative Role ..... Ralph K. Huitt ..... 566

TVA and Power Politics ..................... Aaron Wildavsky .... 576

Joseph de Maistre and the Reaction Against the

Eighteenth Century .................... Elisha Greifer ........ 591

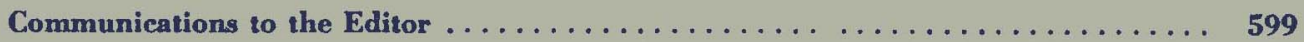

Report of the Advisory Committee on Foreign Relations ............... 601

Book Reviews, Notes, and Bibliography .......... Thomas H. Eliot (ed.) ... 604

Doctoral Dissertations in Political Science ........... William C. Seyler (comp.) 691

News and Notes $\ldots \ldots \ldots \ldots \ldots \ldots \ldots \ldots \ldots$ Ralph A. Straetz (ed.) .. 709

(For list of book revievs, see page 604)

Published quarterly by

THE AMERICAN POLITICAL SCIENCE ASSOCIATION 


\section{THE SUPREME COURT AND AMERICAN ECONOMIC UIFE}

Benjamin Munn Ziegler, Amherst College. A collection of thirty-seven land-mark decisions of the Supreme Court, touching all phases of the relationships between government and business. Concisely excised opinions, clearly introduced. About 304 pp., paperback. Probably $\$ 2.50$. Ready in January, 1962.

\section{THE NEW COMMUNIST MANIFESTO and Related Documents}

Dan N. Jacobs, Miami University, editor. Other documents include Khrushchev's "secret" address to the Party Congress XX, Lenin's Testament with the codicil, the original Communist Manifesto. The 1957 Declaration of the Communist and workers' parties delegates, Mao's "Let a Hundred Flowers Blossom" speech, and extracts from Edvard Kardelj's "Socialism and War." Professor Jacobs provides a general introduction and a headnote for each document.

".... an excellent collection of very important documents .... publishing such material (is) of great value to all of us."-D. A. Tomasic, Indiana University. 1961. 217 pp. Paper $\$ 1.90$.

\section{AMERICAN FOREIGN POLICY IN THE NUCLEAR AGE}

Cecil V. Crabh, Jr., Vassar College. ".... a sound and lucidly written text which can be strongly recommended .... full of excellent and important up-to-date empirical material .... Crabb is generally clear and organizes his material well, and the reader has something to get his teeth into."-H. S. Wolfsohn, The Austrian Journal of Politics and History, May, 1961. 1960. 544 pp. $\$ 6.90$.

\section{MAJOR GOVERNMENTS OP MODERN EUROPE}

Herman Finer, University of Chicago. ".... an admirable text for courses in Comparative Government. It is surely the most readable and the most up-to-date of textbooks in this area .... . it is always refreshing to see so able a writer and scholar as Herman Finer making completely clear what his judgments are instead of hiding them under a bushel in the name of "objectivity'." -Frederick L. Schuman, Williams College. 1960. lxxiv + 736 pp. \$8.25.

Examination copies available upon request to teachers of the appropriate courses. Write for a copy of Row.Peterson's current College Catalog.

\section{ROW, PETERSON AND COMPANY} Publishers of Good Books in Invanston, Illinols, and Fhlmsford, New York Please mention The American Poltricat. Scirnce Review when writing to advertisers 


\title{
An Announcement of Extraordinary elmportance
}

\section{THE STRUCTURE AND FUNCTIONS OF AMERICAN GOVERNMENT}

\author{
Peter H. Odegard, Lecturer
}

Continental Classroom, the well-known college level educational program, will be carried in color over some 170 NBC television stations in 1961-62.

The text for the second semester is American Government: Structure, Problems, and Policies. by Peter H. Odegard, Hans Baerwald, et al. There will also be a collection of documents, and a study guide. All three books will be published by Row, Peterson and Company in inexpensive paperbound editions. (A similar set of three paperback bonks has been, published by Holt, Rinehart and Winston, Inc., for the first semester.)

College credit will be given by an estimated 500 colleges and universities. A set of objective examination questions will be available gratis to instructors at colleges and universities that extend credit for this course to their students.

The course is sponsored by The American Political Science Association, The National Council for the Social Studies, The American Association of Colleges for Teacher Education, and the National Broadcasting Company. Professors Stephen K. Bailey, T. Wilson M. Compton, Pendleton Herring, Evron M. Kirkpatrick, Malcolm C. Moos, Clinton Rossiter, and E. E. Schattschneider are among the members of the Advisory Committee.

The second semester program will begin on Monday, February 5, 1962, and will conclude on Friday, May 25, 1962. The telecast will be made from 6:30 to 7:00 a.m., local time, Monday through Friday each week.

For further information, write as follows:

(a) In respect to the granting of college credit, address Mr. John J. Kelley, AACTE Co-ordinator, Continental Classroom, National Broadcasting Company, 30 Rocke. feller Plaza, New York, New York.

(b) Concerning the textbook, document book, study guide, and examination questions, address College Department, Row, Peterson and Company, Evanston, Illinois.

\section{ROW, PETERSON AND COMPANY} Publishers of Good Books in Evanston, Illinois, and Elmsford, New York 


\title{
THE AMERICAN POLITICAL SCIENCE REVIEW
}

\section{Published quarterly by The American Political Science Association}

\author{
EDITORIAL BOARD \\ HaRvey C. Mansfield, Managing Editor, Ohio State University \\ Wallace S. SAYRe, Associate Editor, Dwight Waldo, University of California, \\ Columbia University \\ Samuel H. BeEr, Associate Editor, \\ Harvard University \\ Otto Kirchheimer, New School for Social \\ Berkeley \\ Harold Stein, Princeton University \\ Alexander Heard, University of North \\ Carolina
} Research

John D. Lewis, Oberlin College

\section{EDITORIAL ASSOCIATES}

Thomas H. Eliot, Book Review Editor, Washington University (St. Louis)

RalPh A. Straetz, News and Notes Editor, New York University

Hrram M. Stout, Washington, D.C.

\section{EDTTORIAL OFFICE}

Managing Editor, APSR

100 University Hall, Ohio State

University, 216 N. Oval Dr., Columbus 10, Ohio
William H. RoBerts, Catholic University

Cecelia M. Kenyon, Smith College

Julaan Feldoman, University of California (Berkeley)

Franklin L. Burdette, University of Maryland

\section{EXECUTIVE OFFICE}

Executive Director, APSA

1726 Massachusetts Avenue, N.W.

Washington 6, D.C.

The American Political Science Review, published quarterly during the months of March, June, September, and December, is supplied to all APSA members. Individual and institutional member. ships are $\$ 15.00$ a year ( $\$ 6.00$ for graduate and undergraduate students). Foreign currency at the official exchange rate will be accepted for foreign subscriptions and foreign membership fees. The equivalent of $\$ 1$ for additional postage should be added for foreign subscriptions.

Current issues are priced at $\$ 3.75$ per copy. Prices of other issues are furnished on request.

Applications for membership, orders for the REviEw, and remittances should be addressed to the Executive Director, The American Political Science Association, 1726 Massachusetts Avenue, N.W., Washington 6, D.C. Notices of change of address should be received in the Washington office by the 5 th day of the month of publication.

Address correspondence about contributions to the Review to Harvey C. Mansfield, 100 University Hall, 216 N. Oval Dr., Ohio State University, Columbus 10, Ohio; books intended for review, to Thomas H. Eliot, Washington University, St. Louis, Mo.; News and Notes items, to Ralph A. Straetz, Department of Political Science, New York University, University Heights, New York 53, N.Y.; advertising correspondence, to the Executive Director at the Washington office.

Articles and notes appearing in the REvrew before the June, 1953 issue were indexed in The Reader's Guide to Periodical Literature. The International Index to Periodicals indexes current issues. Microfilm of the REviEw, beginning with Volume 46, may be obtained from University Microfilms, 313 North First Street, Ann Arbor, Michigan.

Office of publication: Curtis Reed Plaza, Menasha, Wisconsin.

Foreign Agent: P. S. King and Staples, Ltd., Great Smith Street, Westminster, London.

Second class postage paid at Menasha, Wisconsin. Acceptance for mailing at special rate of postage provided for in Section 1103, Act of October 3, 1917, authorized May 12, 1926.

Printed in the United States of America by George Banta Company, Inc., Menasha, Wisconsin.

Copyright, 1961, by The American Political Science Association. 


\title{
The College Department of RAND MCNALLY Announces
}

\section{INTRODUCTORY READINGS IN POLITICAL BEHAVIOR}

\author{
S. SIDNEY ULMER, Michigan State University, Editor
}

This book of 48 selected readings has been collected to define and study the relatively new concept of political behavior. For Part One articles were selected which would present an introduction to political behavior and the social and psychological bases of the concept.

In Part Two, the major portion of the book, the selections illustrate the major conceptual approaches to the study of political behavior. The purpose here is to show the different theoretical and concrete research findings which flow from conceptual variation. Continuity among the subdivisions is furnished through introductory notes which suggest the possibility of relating all concepts, in varying degrees, to the socio-political system.

The book incorporates some of the most recent research in this rapidly advancing field, and the average length of each article-at least ten pages-permits a deeper analysis of the subject than is usually presented. In addition, the book includes a large number of charts, mathematical formulations, and diagrams.
1961
500 pages
$\$ 4.75$ list
$6 \times 9$ inches

\section{DEMOCRACY IN URBAN AMERICA: READINGS ON GOVERNMENT AND POLITICS}

\author{
Edited by OLIVER P. WILLIAMS, Fels Institute of Local \\ and State Government, University of Pennsylvania \\ and CHARLES PRESS, Michigan State University
}

The Editors of this book of readings have chosen articles which emphasize the problems pertaining to the role and function of local government in the democratic system. The assumption of this approach is that the "facts" about municipal government are those matters most easily learned and most easily forgotten. Therefore, the facts are marginal matters, and the book is based on an organizing theme (democracy) instead of being randomly topical. The two principal points the articles illustrate are that American communities differ widely from one another and, therefore, no single characteristic model can be created, and that people should stop viewing local government in isolation. Considerable stress is placed on policy development process and the politics of various phases of urban government such as metropolitanism, administrative reform, substantive functional areas, and the administrative process. To achieve this the articles are recent and have been written by authorities in the field, including a number of sociologists. The book is designed to be used either as a text or secondary readings. The readings are sufficient in length, to permit the authors, many of whom are sociologists, to develop their arguments.
1961
- 500 pages
- c. $\$ 5.50$
- $6 \times 9$ inches

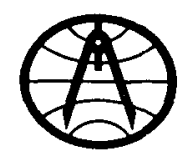

College Department

RAND M S NALLY \& COMPANY P. O. Box $7600 \cdot$ Chicago 80, Illinois 


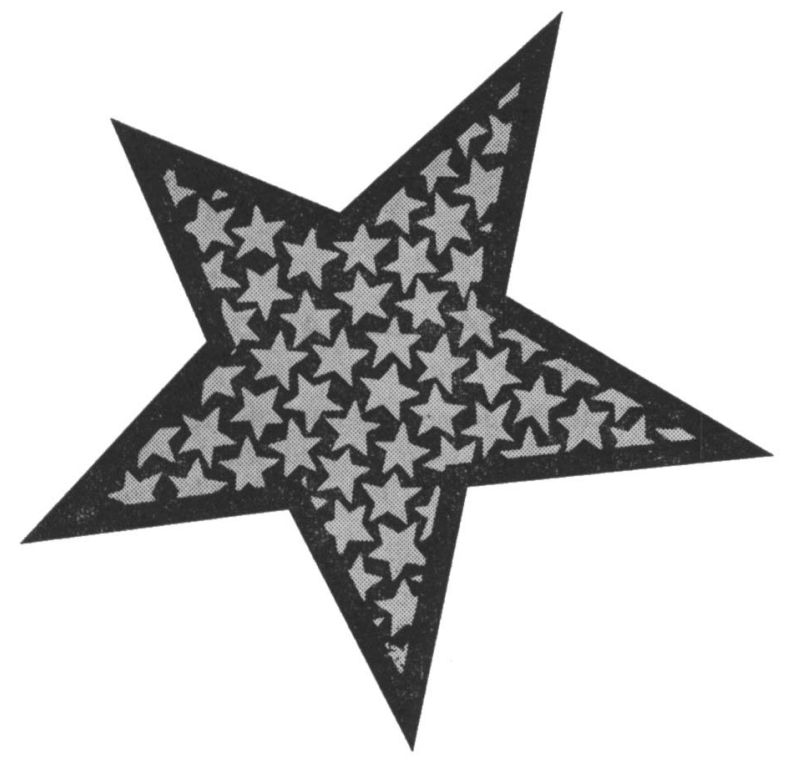

\section{STATE AND LOCAL GOVERNMENTS}

by RUSSELL W. MADDOX and ROBERT F. FUQUAY, both Associate Professors of Political Science, Oregon State University

This comprehensive and up-to-date text sets forth the basic principles, institutions, and functions of American government at the state and local levels. By concentrating on major facts and problems, the authors have kept the book manageable in size and interesting to read. After briefly describing the historical development of our state and local institutions, the authors discuss federal-state relations, basic governmental principles and processes, and the structural characteristics of state governments. The final chapters are devoted to major functions of state and local governments. Illustrative material is used throughout, and conflicting viewpoints on controversial subjects are clearly presented. Examination copies available November 1.

\section{GOVERNMENT AND POLITICS IN THE UNITED STATES}

by GUY B. HATHORN, Associate Professor of Government and Politics, University of Maryland; HOWARD R. PENNIMAN, Professor of Government, Georgetown University; and HAROLD ZINK, Professor of Political Science, The Ohio State University

In this new full-year text, the authors unfold a broad, realistic picture of all levels of American government-origins, history, structure, and operation. The book's timeliness is apparent in its full coverage of the 1960 campaign and election, the reapportionment in the House of Representatives resulting from the 1960 census, the Supreme Court decisions and congressional activities through the summer of 1960. 1961, 790 pages, $\$ 8.00$

Both texts are in the VAN NOSTRAND POLITICAL SCIENCE SERIES, Franklin L. Burdette, Editor

\section{VAN NOSTRAND COMPANY, INC. 120 Alexander Street \\ Princeton, New Jersey}

